\section{Visión Electrónica Más que un estado sólido \\ https://doi.org/10.14483/issn.2248-4728}

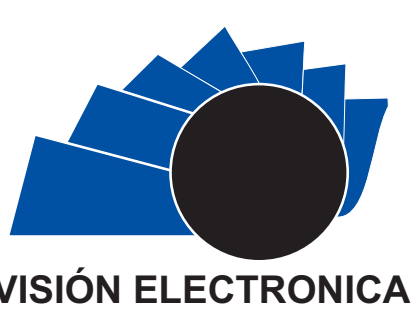

A Current Vision

\title{
State of the art in cooperative robotics applied to rescue of victims
}

\author{
Estado del arte en robótica cooperativa aplicada al rescate de víctimas
}

\author{
Stephanie Lizbeth Reyes Beltrán ${ }^{1}$, Mónica Marcela Salamanca Bocachica², \\ Gustavo Adolfo Higuera Castro ${ }^{3}$
}

\section{INFORMACIÓN DEL ARTICULO}

Historia del articulo

Enviado: 08/09/2018

Recibido: 25/09/2018

Aceptado: 12/10/2018

\section{Keywords:}

Localization,

Mobile communication,

Multi-agent robots,

$\mathrm{RC}$,

Victim rescue.

\section{Palabras clave:}

Localización,

Comunicación móvil,

Robots Multi-agente,

$\mathrm{RC}$,

Rescate de víctimas.
ABSTRACT

The present article, in the context of a documentary research carried out and interpreted to be taken as a baseline in research for the ROMA Autonomous Mobile Robotics Group of the Francisco José de Caldas District University, describes the state of art of the applied $\mathrm{RC}$ to the rescue of victims. The revision is established chronologically in the last fifteen years; in Latin America; and focused mainly in Colombia. They are used as sources: The Google Schoolar database, and articles from the electronic engineering journals indexed for the year 2017 in COLCIENCIAS. As a product thrown, a particular model of communication technology used in CR is presented in the Colombian context.

\section{RESUMEN:}

El presente artículo, en el contexto de una investigación documental realizada e interpretada para que fuera tomada como línea de base en investigaciones para el grupo de Robótica Móvil Autónoma ROMA de la Universidad Distrital Francisco José de Caldas, describe el estado de arte de la RC aplicada al rescate de víctimas. Se establece cronológicamente la revisión en los últimos quince años; en Latinoamérica; y enfocada principalmente en Colombia. Se utilizan como fuentes: la base de datos Google Schoolar, y artículos de las revistas de Ingeniería electrónica indexadas para el año 2017 en COLCIENCIAS. Como producto arrojado se presenta un modelo particular de la tecnología de comunicación empleada en RC en el contex to colombiano.

\footnotetext{
BSc. In Telecommunications Engineering, Universidad Distrital Francisco José de Caldas, Colombia. Current position: Laboratories of the Universitaria Agustiniana, Colombia. E-mail: auxtelecomunicacionesdia@uniagustiniana.edu.co. ORCID: https://orcid.org/0000-0003-4818-5166.

${ }^{2}$ BSc. In Telecommunications Engineering, Universidad Distrital Francisco José de Caldas, Colombia. Current position: Technical leader in IBM. E-mail: msalaman@,co.ibm.com. ORCID: https://orcid.org/0000-0002-2635-6035.

${ }^{3}$ BSc. In Engineering in telecommunications, science and technology, Universidad Distrital Francisco José de Caldas, Colombia. Current position: Professor and researcher of ROMA at Universidad Distrital Francisco José de Caldas, Colombia. E-mail: hahiguerac@uditrital.edu.co. ORCID: https://orcid.org/0000-0001-9691-789X.

Cite this article as: S. L. Reyes-Beltrán, M. M. Salamanca-Bocachica and G. A. Higuera-Castro, "State of the art in cooperative robotics applied to rescue of victims", Visión electrónica, algo más que un estado sólido, vol. 1, no. 2, Special edition, july-december 2018. DOI revista: https://doi.org/10.14483/issn.2248-4728
} 


\section{Introduction}

Due to climatic factors and the contingencies of violent intervention at a social level where the human being is subdued (accidents and attacks), solutions have been sought at a technological level to minimize the loss of human lives; for example: at the moment of rescuing victims after some type of catastrophe. Therefore, different technological developments have been carried out, among which Cooperative Robotics (CR) is included. Particularly, in Latin America, research has been carried out in the field of CR focused on industry, automation, among others. However, there is little literature emphasized for its application in the social field.

The origin of the CR can be found in the work of Fukada, Nadagawaka, Kawauchi \& Buss [1] in which an approach to the coordination of multiple homogenous and heterogeneous robotic units is described. Ever since, investigations have been developed in the area. Caloud et al. [2] and Norelis [3] applied a traditional control architecture based on gliders to a block movement task, implemented with two robots. Kube et al. In [4] and [5] a series of simulations of robots is described, executing a simple collection of behaviors that are incrementally transferred to physical robots. Barman et al. [6] report a bed of preliminary tests for the study of the control of multiple robots in a task involving playing soccer. Parker [7-8] describe an architecture for sharing tasks based on behaviors for the control of groups within heterogeneous robots, and it is displayed in a group of four physical robots that perform tasks of cleaning toxic waste and pushing blocks. Donald et al. [9] reported the theoretical basis for the implementation of manipulation on cooperative tasks with a pair of mobile robots; Beckers et al. [10], demonstrated it in a group of four robots grouping randomly distributed disks through purely indirect communication (stigmentric communication).

As a matter of fact, thanks to the impact that this area has acquired, a robotic soccer tournament has been provided since 1997: RoboCup, which has served as a great laboratory for the validation of $\mathrm{CR}$ models, [11]. On the other hand, in Colombia research and development in $\mathrm{CR}$ is recent, and so far the investigation is being carried out regarding the origin of the topic and its development; It can be highlighted that the generation of algorithms and the interest in the methods for the behavior of animals that work in teams for a common good have gained relevance.

Consequently, this review paper is organized in the following way: in the Introduction the document is presented and the relevance it has upon cooperative robotics and the implementation within the specific topic. Then, in the methodology, the temporary space in which the research is carried out is laid out as well as how the document is accomplished. Subsequently, the categorized and classified documentary development of all the collected information is exhibited. Finally, the conclusions are presented, and the ideas that can be extracted and interpreted are argued to make of this research a baseline in future perspectives.

\section{Methodology}

In the last 15 years, research has been carried out on CR in which the following categories are highlighted, according to the field applied: Industry, where there are documents related to Control Architecture, Decentralized Control and Centralized Control; in Education which contains evidence of Research, Design and Development; in Security where there are location and detection; Health, and Rescue of victims where emphasis is placed on locomotion and research projects in the magazine Visión Electrónica; in this last item, the present paper review is accentuated in which articles published in the magazine Visión Electrónica will be included: something more than a solid state. The bibliographic search is carried out in the Google Scholar database using the descriptors: revision, CR, CR for Rescue of Victims, state of scientific knowledge. The records obtained range between 80 and 90, with the keywords used.

When analyzing the documents, those that were developed in Latin America were selected in preference to Spanish, and emphasizing Colombian exponents in order to provide information on the formal and specific aspects of the subject that are appropriate for: a review; a critical reading of documents; the implementation of a bibliographic review; an accessible knowledge; and the elaboration of mental and / or conceptual maps.

For this paper review the Method by indices is used for the construction of the overhaul (vertebrate from a general index) [12], in which some categories and subcategories are established (for the case of Victim Rescue), shown in the Figure 1 and Figure 2. 


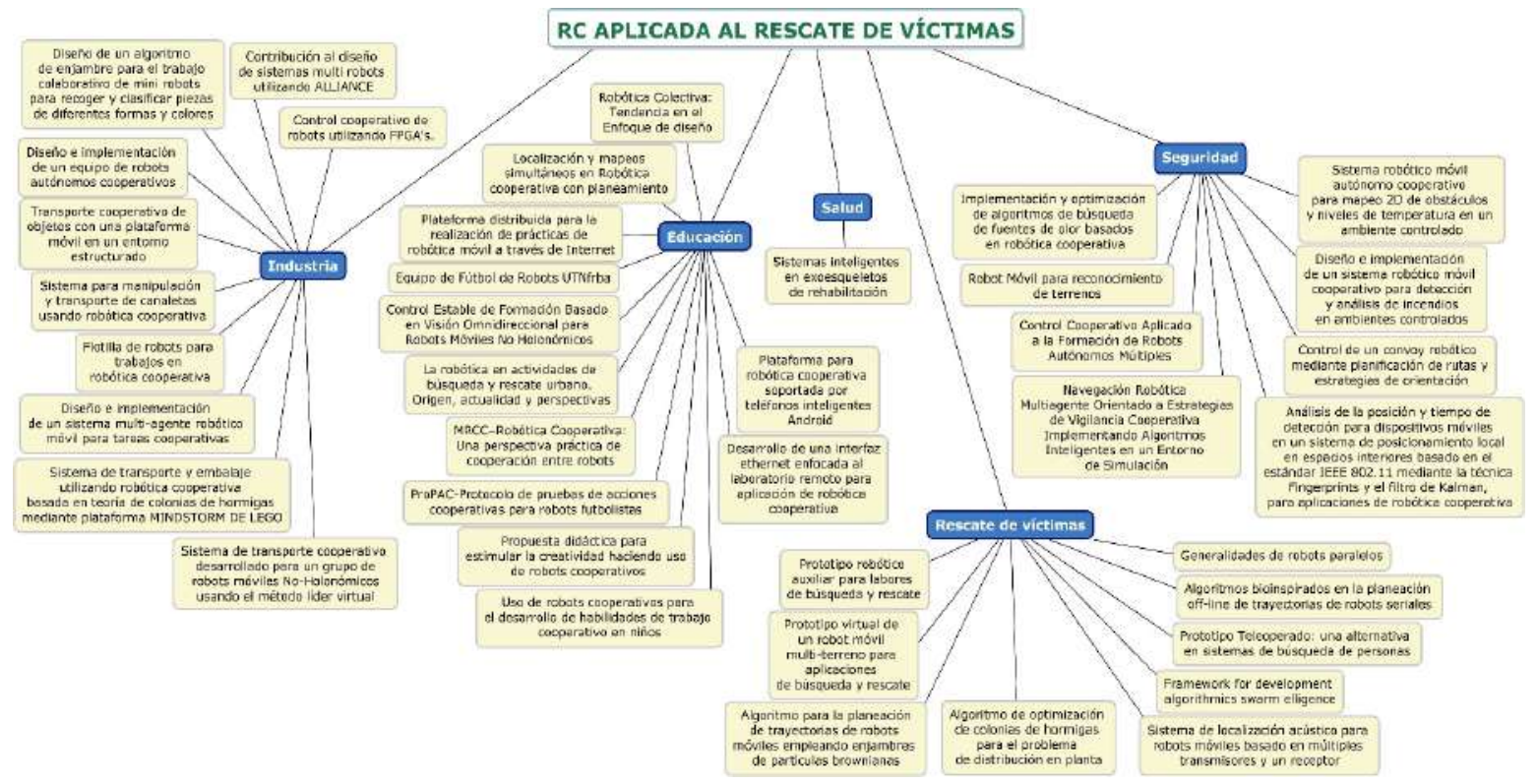

Figure 1. Research model for the developed state of art; this methodology was validated by the evaluation of experts from the ROMA research group of the Universidad Distrital Francisco José de Caldas. Source: own.

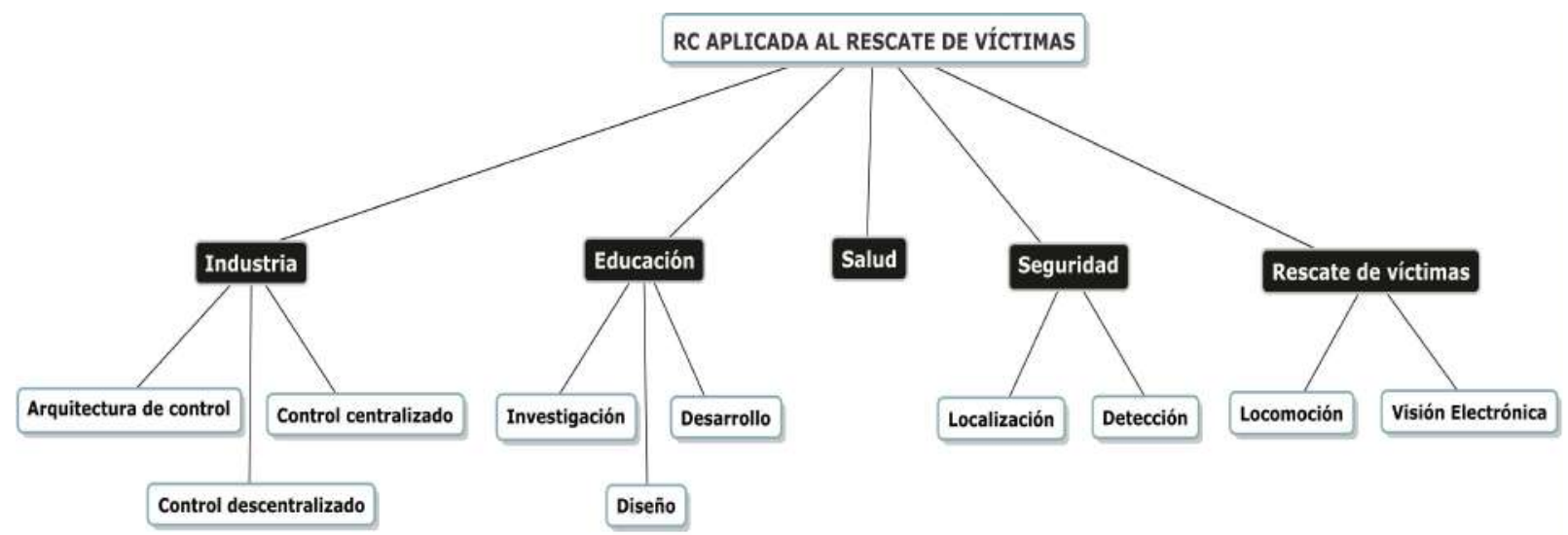

Figure 2. Subcategorization of the research model for the developed state of art. Source: own.

\section{Development}

\section{a. Industry}

This category is established because within the research there are developments and studies for the processing of raw material to reach the final product, using cooperative robotics for such system, so that the group of robots finds organizational solutions among themselves.

\section{l. Control architecture}

Initially, in [13], the ALLIANCE 1 control architecture and its successor ALLIANCE ${ }^{4}$ are carefully studied, making modifications in its formal model and proposing new heuristics aimed at obtaining a better assignment, resulting in a better performance of the equipment. The case study focuses on an object collection task implemented using state machines and reactive behaviors.

\footnotetext{
${ }^{4}$ ALLIANCE is a software architecture that facilitates the tolerant cooperative control of failures of heterogeneous mobile robot groups performing a mission composed of several weakly coupled tasks that can have order dependencies.

${ }^{5}$ FESTO is a German multinational company based in Esslingen. His specialization is in products and services for control, industrial automation, pneumatics and electronics

${ }^{6}$ FPGA it is a programmable device that contains logic blocks whose interconnection and functionality can be configured at the moment by means of a specialized description language.
} 
.On the other hand, in [14] the design of a system of two robots able to perform a task in a cooperative way to move a rigid bar through a defined trajectory is described; to achieve this purpose, three Robotino $\AA$ by FESTO, mobile robot platforms are used, each of which has been installed with a threedegree-of-freedom manipulator -provided with a clamp on the edge- which is controlled through a Atmega 164p microcontroller. For the development of the control system a centralized cooperative control system is implemented in a module FPGA Spartan3E Starter Kit. The control algorithm and the HMI are developed in the LabVIEW programming environment.

Similarly, [15] describes in the research line the transport of objects by means of different strategies that range among pushing, holding and dragging objects is described. The focus of the article is to show the development and implementation of a CR platform applied to the transport of long objects through a structured environment using the tools provided by the Lego Mindstorms RCX 2.0 kit and the autonomous mobile robotics research group ROMA. The development of the environment where the final tests were carried out consisted of a $1.5 \mathrm{~m}^{2}$ matte black sheed of wood with white strips on the left end, whose length was $0.21 \mathrm{~m}$ by $0.018 \mathrm{~m}$ wide. As part of the environment, the objects had a box of $1 \mathrm{~m}$ in length, a box of $0.35 \mathrm{~m}$ in length and a cylinder of $1.8 \mathrm{~m}$ in length. The platform has a pair of robots called master and slave whose physical characteristics allowed to drag the object, in this way each robot had a set of sensors distinctive from the kit, so in an early stage, the master robot relied on a contact sensor, and a couple of rotation sensors, while for the slave there was a contact sensor and a pair of light sensors, the locomotion system implemented due to its benefits was the caterpillar given the fact it offered more contact surface when transporting the object. The communication of the robots was carried out by means of an infrared link and handling characters in the range of 0 to 255 (only integers).

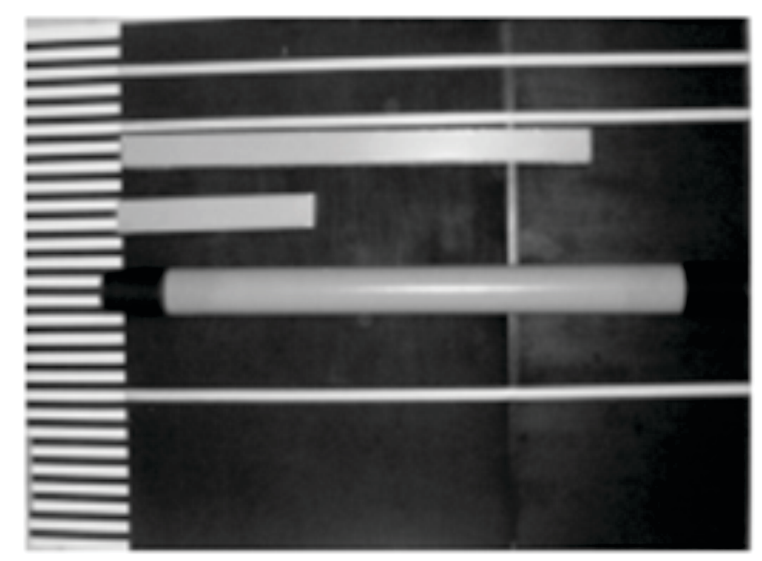

Figure 3. Structured environment. Source: own.

[16], aims to develop the design and optimization of interaction rules for a search party on classification of pieces by colors, where robots try to achieve temporary efficiency in carrying out a task collectively. The beginning of the work in the line of artificial intelligence in the hotbed of research SYNAP

\section{1l. Decentralized control}

On the other hand, [17] describes the design of a group of mobile robots that consists of three independent and autonomous agents interacting with one another under a cooperative behavior architecture. The following aspects are considered: Traffic control with movement patterns; the function of each robot will be to contribute to the solution of the global group task and for such task, each robot will have the ability to wirelessly communicate its status to the remaining agents. The agents will be homogeneous, with sensors that allow them to obtain information from the environment. A monitoring center similarly connected to the wireless network will be used, in which variables and geographical arrangement of the robot within the environment will be displayed. It should be pointed out that this central (PC) is not an active member of the cooperative system, that is to say, at no time it will give orders or commands to the robot team, but rather it will be used as a tool to expand the electronic vision of the processes within the

\footnotetext{
ALLIANCE is a software architecture that facilitates the tolerant cooperative control of failures of heterogeneous mobile robot groups performing a mission composed of several weakly coupled tasks that can have order dependencies.

${ }^{5}$ FESTO is a German multinational company based in Esslingen. His specialization is in products and services for control, industrial automation, pneumatics and electronics. ${ }^{6}$ FPGA it is a programmable device that contains logic blocks whose interconnection and functionality can be configured at the moment by means of a specialized description language.
} 
total system. A microprocessor will be responsible for the control of actuators as well as reading of sensors, thus constituting the lowest level layer. A second microprocessor will control the communication module between agents and the core of the cooperative architecture.

According to this last strategy, in [18]. The decentralized control system developed in this work has specific advantages, since it deploys the possibility of changing arragement, modifying the role of robots, restricting the dynamics of the system and assuming the loss of a robot during the mission without major complications, achieving the group of robots fulfills the targeted objective. In order to have versatility in the configuration of mobile robots, cooperative control is designed bearing into mind the movement of a particle in space, assigning it a travel speed in the global axis. Subsequently, the control laws were implemented in a group of ArduinoRobot physical robots from the company Arduino9. The design was conceived from an omnidirectional platform. This design was done in order to correct mechanical aspects such as the location of the center of mass or stress concentrations in geometries under reduced thickness. As a result, a three-robot fleet equipped with the necessary sensors is delivered to continue with the next stage of the project.

In other direction, [19] shows a system focused on selection and packaging, the final stage of most industrial processes. The problem was approached through robotic agents with different characteristics that function emulating the organization of an ant colony, making these stages an efficient and effective process with great flexibility when facing changes in production. The characteristics of the random and pseudodependent movements of the environment make the location of the final destination of the boxes a dynamic and autonomous process.

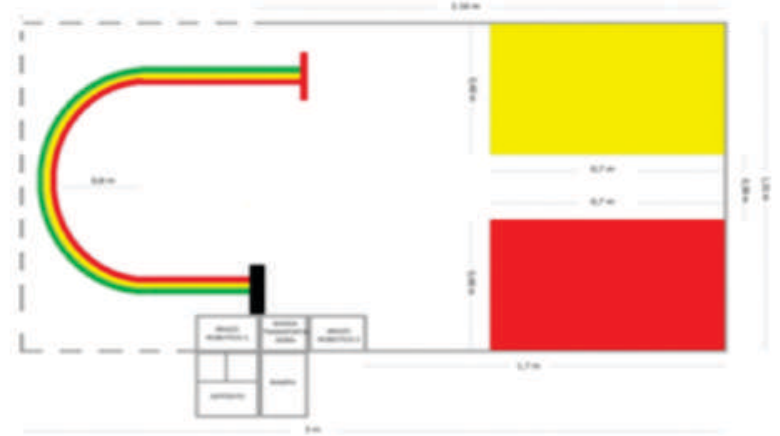

Figure 4. Prototype model. Source: own.

The total synchronization of the system depends on the efficiency of the communication, so by not sparing resources the correct connection among the robotic agents was guaranteed. One of the great tools that allowed optimizing communication processes and route calculation was the use of NXC software, which provided the possibility of performing remote functions, in addition to calculating routes, by handling variables in floating point and operating arrangements, among others. The HMI was implemented in a computer using LabView ${ }^{\circledR}$ and in a NXT CPU simultaneously. Finally, an efficient, dynamic, autonomous system was generated and undoubtedly, a viable model that can be extrapolated with small modifications on a real scale.

\section{Ill Centralized control}

[20], presents two (2) cooperative robots of the RSCT (Robotic System of Cooperative Transport), which have an analogous design, in which the only difference between both agents is the side to which the lock of the gripper (final effector) is located in each manipulator, based on the position of each agent with respect to the gutter during transport. The manipulator and the mobile chassis are the only subsystems with a partially mechanical nature. The combination of two methods (a sensor associated with each one) is proposed to demarcate the trajectory the robots perform, as well as a third sensor for the detection of obstacles.

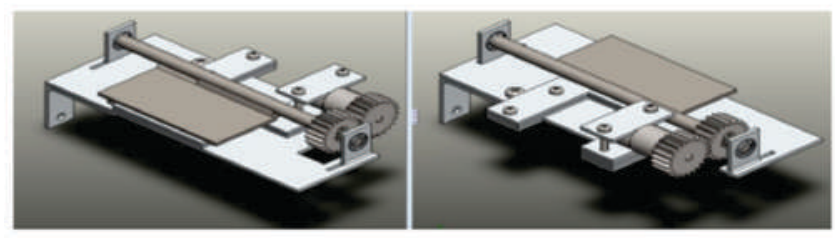

Figure 5. Design of the Grippers. Source: own.

Arduino is an open source company and open hardware. 
On the one hand, and in coherence with the above, in [21] the design of an entire system was carried out where two mobile robotic entities can perform specific tasks thanks to their displacement and the coordination of their actions; the latter in order to venture into the field of artificial intelligence. The machines help each other to achieve a goal, and to achieve it, they use the best skills of the robot-individual. The group of Robots and Intelligent Machines of the UPM has developed the SMART1 system, a group of agents (robots) whose main purpose is achieve the best configuration to meet a goal. If an agent cannot complete its mission, another agent (s) come to its aid, to such an extent that they can substitute it in the original task or help it to finish it. In addition, each robot has a bluetooth communication system to contact a central checkpoint from which the tasks to be performed are established.

On the other hand, [22] describes a planning and movement control scheme for a cooperative transport system, which consists of a single object to transport and multiple non-holonomic autonomous mobile robots. In addition, this document presents the design of a cooperative control that allows to establish and maintain a specific geometric formation for a group of mobile robots while they are moving. The LeaderFollower approach control strategy was used, but a virtual leader based on ROS was implemented because the main idea is to maintain the aligment all the time, minimizing the error as low as possible. As a result of the research, a cooperative control system that allows a set of robots to maintain specific training while the group performs a predetermined mission was demonstrated by a ROS-based simulation.

\section{b. Education}

This category has a widely number of investigations, since it seeks to improve the amenities for students and members of the educational community through technological development; besides, these studies can be emphasized and brought to other branches at a business or social level.

\section{Research}

Initially, in [23] techniques (SLAM) have been created to allow a robot, while traveling in an unknown environment, to build a map of its environment while estimating its current position. Although this problem has been extensively studied in the last two decades, little effort has been devoted to the adaptation of SLAM to the context of $\mathrm{CR}$, which could allow the development of more efficient, profitable, reliable and robust solutions. This article presents a survey in both SLAM Cooperativa and in SPLAM (Simultaneous Planning, Location and Mapping), discussing the limitations in cutting-edge approaches and identifying directions for future advances in this field of research.

In another context, [24] seeks to provide relevant information in this field of research and development, so that in the near future it can be provided with appropriate technology for the care of eventual disasters, particularly in urban search and rescue activities; the document is the result of the study and reflection of the Research Group in Autonomous Mobile Robotics (AMR) about the techniques and procedures of urban search and rescue of victims, as well as the technology to support this type of activities developed at present time, in order to identify alternative solutions to the national problem in this field.

In [25], this work seeks to present an integration model corresponding to the projects framed in the large Agentcoop project developed in the Systems Department of the Faculty of Engineering at Pontificia Universidad Javeriana. A work plan will be developed where a collection and appropriation of concepts will be carried out and a theoretical model of integration will be considered, this model will be applied to the development and the corresponding tests will be performed bringing out a documentation of results and description of the procedures carried out, as well as a software implementation corresponding to the model proposed. Though, [26] describes the School Technology Activity (STE) as a proposal in the resolution of problems by students, which can only be addressed from the CR, and through which creativity is strengthened. In response to a didactic problem solving strategy, robotics is used in a learning environment in which students start off from the interpretation and analysis of their immediate environment, in order to embrace the association of technology.

\footnotetext{
${ }^{10}$ Polytechnic University of Madrid

${ }^{11}$ A robot is holonomic if all the constraints to which it is subjected are integrable in the positional restrictions of the form: The variables are the coordinates of the system. When a system contains restrictions that cannot be written in this way, it must be non-holonomic.

${ }^{12}$ Robot Operating System

${ }^{13}$ Simultaneous Localization and Mapping

Visión Electrónica: Algo mas que un estado sólido ISSN 1909-9746 E-ISSN 2248 4728 Volume 1 number 2- Special edition July-December 2018
} 
This environment has a didactic guide for the teacher in which a (ATE) is proposed based on the resolution of problems and involves three main sections: setting the central themes of the activity, introduction to problem solving from situations close to their environment, and approach and design of possible solutions for the implementation with the robots from their programming.

\section{lll. Design}

In [27] describes the trend and approach of control architectures for multi-robot systems. An architecture displays a construction approach or philosophy that establishes the logic of control for a multi-robot system. From the latter perspective, there is a tendency in the design of multi-theft systems and it points to Biology, specifically to the area of ethology. The reasons point to the feasibility of implementation, in physical and logical terms, of the scope of biological systems with a strictly reactive behavior and the possibility of generating second-level behaviors: instinct and learning (based on reactive structures).

Now, in [28] a control algorithm based on leader tracking for the autonomous navigation of a team of non-holonomic mobile robots maintaining a desired alignment is presented. Control errors are defined in terms of the instantaneous positions of each robot and their desired position within the alignment, with regard to the group's leading robot. For sensing the relative positions, the leading robot is the only one equipped with an omnidirectional vision system. The stability of the proposed system is tested according to Lyapunov's theory and a robustness analysis is carried out before certain estimation errors. The main objective for the follower robots is to reach a desired alignment and safeguard it while following the leading robot.

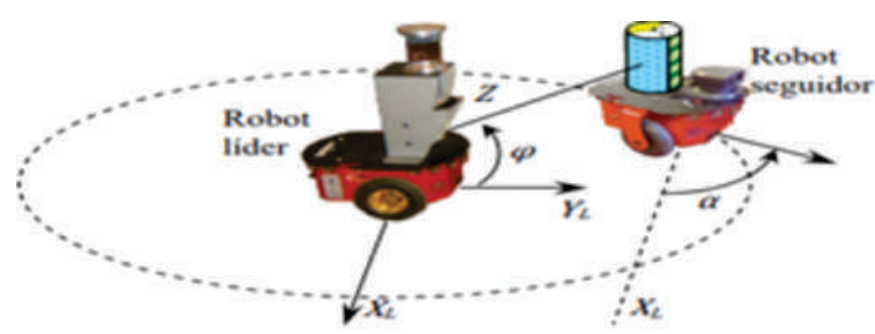

Figure 6. Multirobot scheme. Source: own.

Finally, in [29], the design and development of a set of tools to develop robotics projects, specifically CR,

\footnotetext{
${ }^{14}$ Ethology studies the behavior of animals in their natural environments
}

through devices with Android operating system is presented. The first tool is a library developed for Android that encapsulates common tasks in CR such as communication requirements, variable control and cooperation among agents. The second is a library for the Arduino ADK card that makes communication and variable handling compatible with the Android library. Finally, the third tool consists of an application that validates the library for Android implementing a common application in $\mathrm{CR}$, the alignment control. The alignment control application starts with the design and construction of three robots of differential locomotion, and ends with the design and implementation of an application that controls the alignment from the images captured by an external camera.

\section{lll. Development}

For the reasons set up above, in [30] a distributed platform that allows students to access the available robots in the laboratory through the Internet is presented. Through this platform, a remote environment is created in which students can carry out different experiments on several computers, with a flexible schedule. The system can generate events based on three different causes; when: the customer interacts with the graphic components, through a timer that synchronizes the processes and through a thread that by means of asking CORBA requests to the identification server, controls the presence of the robots in the system. This application acts as a CORBA, customer, so it is capable of requiring services to the actuators and sensors of the robots.

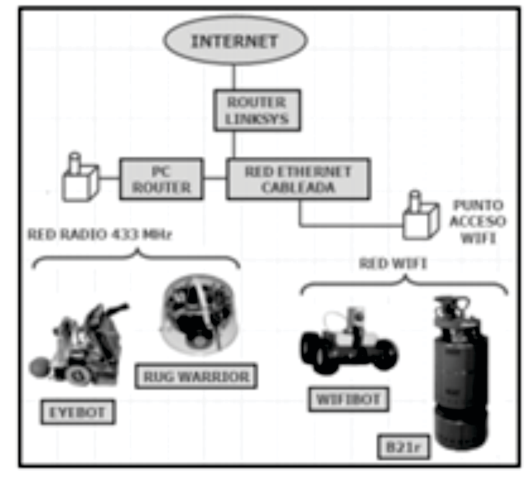

Figure 7. General architecture of the communications system. Source: own. 
Instead of, [31] the description of the robots football team UTNfrba functioning is presented. The team consists of five players and a virtual coach, each of them is an independent agent and they communicate with one another through a platform in real time, counting on a messaging system, traffic lights, among others. Each player makes use of different skills and tools, such as path control, route planning, and prediction of the movements of the environment. The virtual coach is in charge of directing the team, indicates the realization of tactics and controls the correct distribution of the team line up through a fuzzy logic engine. The virtual coach is responsible of managing the global operation of the team and generating a cooperative work among robots.

Nevertheless, in [32] the tests design process to be executed was focused, firstly, on the individual functioning of the physical robots taking into account that at the time of designing the ProPAC protocol there were two generations of robots, the participants in the LARC 2010 and the participants in ROBOCUP2011, through these individual tests it was possible to determine which generation was the most apt to perform the tests that involved more than one robot. The second key element for this protocol was to evaluate cooperative actions in controlled environments and in a competitive environment.

Regarding this, in [33] a contribution to the QUEMES project is described. It is a proposal for education in technology that addresses three components: the construction of differential mobile robots, the graphic environment of event-oriented programming and pedagogical activities for children. The goal is for children to learn to work cooperatively by observing how robots interact to solve a problem weakly structured jointly. Students only define the interactions among the robots and the reactions they must have to the events; when compiling the program, the necessary codes for the autonomous control of the robots are generated automatically. QUEMES, in addition to providing a hardware and software platform, also proposes a series of technological school activities, where students learn the basic principles of mechanics, electronics and programming, necessary for understanding the operation of robots, as well as reflecting on the importance of cooperative work.

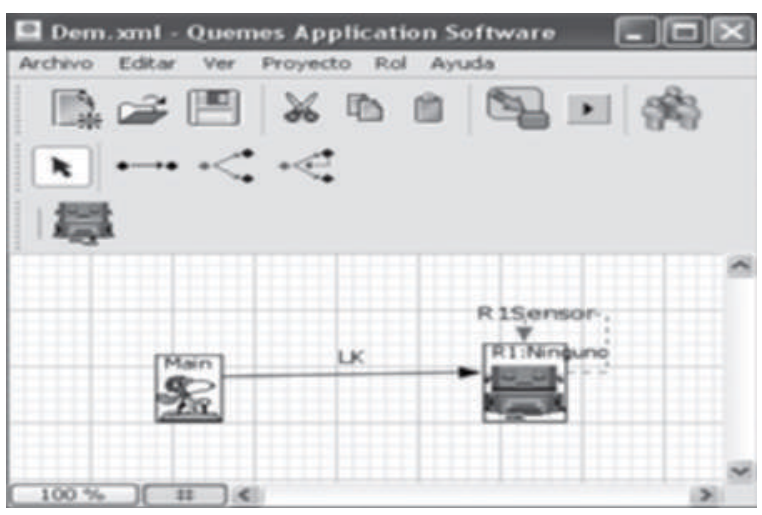

Figure 8. Programmable platform. Source: own.

On the other hand, in [34] a system that allows to develop the concept of CR of suggested, by means of a remote laboratory whose objective is to manipulate and control robotic mobile devices, which can interact with one other depending on the purpose of the user, and additionally allow control from a remote place monitored by a camera.

\section{c. Security}

In this category there are developments to perform discards and warnings that show that something is out of the ordinary and therefore there may have some level of danger.

\section{l. Location}

For [35], the abilities of several simple mobile robots are related to the fulfillment of a single task, in this case the objective is to map certain area to be able to locate obstacles and temperature changes, in order to achieve this, the implementation of a mobile multi robotic system with the purpose of demonstrating the effectiveness of the method on systems with a single robot is carried out.

In addition, one of the challenges of the work presented is the creation of algorithms to solve the problem called SLAM in multi robotic systems. The system has a central controller which is responsible for guiding and distributing the robots through wireless communication, this central controller has a simple interface that simulates the environment of the robots in real time for the visualization of obstacles and changes of temperature with an upper view in 2 dimensions.

\footnotetext{
${ }^{15}$ CORBA is a standard defined by the Object Management Group (OMG) that allows various software components written in multiple programming languages and running on different computers, to work together; that is, it facilitates the development of distributed applications in heterogeneous environments.

${ }^{16}$ UTN (National Technological University) Buenos Aires Regional School

${ }^{17}$ Latin American Robotics Competition

${ }^{18}$ QUEMES it is a proposal of learning in technology education using cooperative robots.

Visión Electrónica: Algo mas que un estado sólido ISSN 1909-9746 E-ISSN 2248 4728 Volume 1 number 2- Special edition July-December 2018
} 
On the other hand, in [36] the team proposes to develop a Wireless Mobile Robot that serves as a tool to solve the problem of land recognition, which would have the ability to move through places inaccessible to humans and at the same time, show real-time images that serve to trace a trajectory, which can be used to generate a better image used for the location of people or objects; it is essential for this tool to have a control easily manipulated by the assigned user.

For [37], the control area of multiple autonomous robot alignments currently turns out to be a very active research area, due to the large number of potential applications of these systems. In this summary, the mathematical model of a vehicle with four rotors is described, and the results obtained in the control of trajectory tracking and orientation in 3D space, which will later be used to control alignments based on these vehicles.
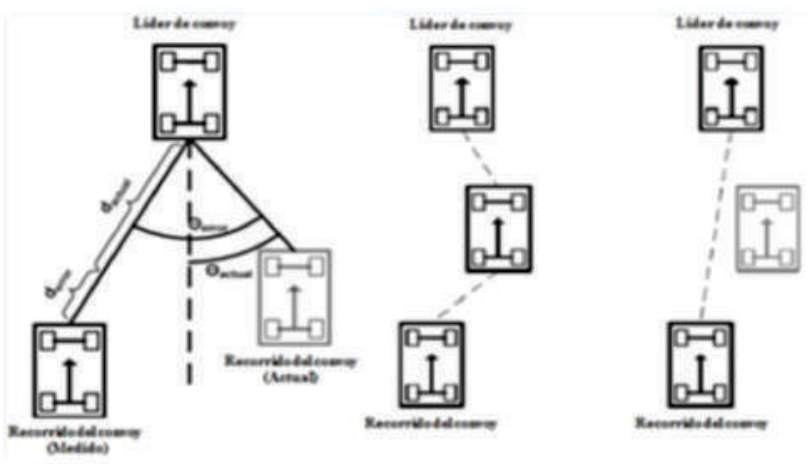

Figure 9. Scheme of operation of the platform. Source: own.

And in [38], a state of the art is presented regarding control methods implemented in robotic convoy systems on mobile platforms that can be used for the planning of routes or trajectories, orientation, perception of environments and control systems in which the measurement, analysis and interpretation of various variables and their subsequent implementation are involved. A review of research articles in bibliographic indexes and databases on control methods applied in convoy systems was made in order to show progress, trends and application methods.

\section{ll. Detection}

Inside [39] this project different elements for a correct navigation and teleoperation of a mobile cooperative robotic system are included. Within these elements, it is important to emphasize the video camera, which transmits in real time the environment through which the robotic platform moves and it is controlled by the movement of the user's head. In addition, there is a graphical interface, which allows to visualize the behavior of the different sensors, remotely through WiFi type communication. The project focuses on the help that the robotic system can offer in areas of extreme danger in the sense of navigation, recognition and analysis in a fire event.

In [40], the search and detection of chemical substances such as alcohol and cologne is developed through the simulation and implementation of search algorithms for odor sources in cooperative mobile robots through a distributed control system. The robots were equipped with chemical sensors MQ-3 that performed the detection of chemical components prevalent in the environment and ultrasonic proximity sensors that allowed autonomous navigation. In order to know the dispersion of the proposed volatiles, a mapping consisting of 13 dispersion maps obtained through the construction of a mobile mapping robot located in different controlled environments under constant temperature and humidity conditions was done. With the maps obtained, environments were developed in the V-REP software, where the search and detection of odor sources using mobile robots was simulated, in which 3 search algorithms were implemented: zigzag, random and guided in language Python ${ }^{19}$.

[41], seeks to a solution based on IEEE $802.11^{20}$ standard, since it is the mostly implemented network in closed spaces. This solution can be based on Fingerprints technique or propagation models. But due to the complicated modeling of the RF signal, in this work a solution using Fingerprints is proposed. One of the facilities of this technique is the possibility of taking advantage of the function of most mobile devices to measure the RSSI ${ }^{21}$ parameter of the various access points of interest. The Kalman filter was implemented considering a linear relationship between several measurements of the RSSI parameter in a same test point in order to try to reduce these variations even more. It can be seen that in [42], the implementation of computational methods that propose cooperative solutions to a team of multi-robotic agents in the tasks of navigation on an environment is proposed. The objective is to minimize the total time of exploration on

\footnotetext{
${ }^{19}$ Python is an interpreted programming language whose philosophy emphasizes a syntax that favors a readable code.

${ }^{20}$ IEEE 802.11 specifies the operating rules of a wireless local area network (WLAN).

${ }^{21}$ Indicator of received signal strength.

Universidad Distrital Francisco José de Caldas
} 
an environment. In order to achieve this, a software tool is developed, such tool provides a simulated approach to $\mathrm{SMA}^{22}$, events, which will allow the scientific implementation of certain softcomputing techniques that suggest cooperative solutions in the navigation of a static environment. It is remarkable that the algorithm constituted by artificial neural networks (ANN) shows better performance in exploration compared to proposals of the state of the art.

\section{d. Health}

Within this category there are developments to improve the life quality of people who either due to illness or the type of work they have done throughout their life, have had a deterioration in their health at the psychomotor level.

In [43], it is shown that disability due to deterioration of motor skills or accidents in economically active persons is important, with data provided by the INEGI ${ }^{23}$ on the Economically Active Population, Gross Domestic Product and Population of the Disabled, considers that the investigations aiming to extend the impact of CR in the rehabilitation of members and / or permanent assistance through robotic exoskeletons are a mechatronic system, which entails the union of several disciplines.

\section{e. Rescue of victims}

In this category there are designs and implementations where the developments carried out within the other identified areas can be used (industry, health, safety).

\section{l. Locomotion}

Dentro de [44], se plantea el diseño de un prototipo virtual de robot móvil capaz de operar por aire o tierra, desplazándose en diversos entornos de desastre mediante la reconfiguración de su sistema de locomoción, permitiéndole así, mejorar la movilidad del robot al realizar tareas de búsqueda, reconocimiento y mapeo, y ampliación de cobertura en comunicaciones, las cuales representan un factor clave en los tiempos de monitoreo y acción. Al ser un prototipo virtual, la validación del diseño del robot móvil se encuentra en desarrollo mediante programas computacionales de simulación y análisis de sistemas multicuerpos, lo cual permitirá exportar un diseño validado a un simulador de entornos de desastre para evaluar su comportamiento y rendimiento con el fin de determinar la factibilidad para su construcción física.

In [45], an application of great global interest is shown, which consists on using rescue robots going through the task of detecting victims in places that are in emergency conditions, specifically intended for the assistance of rescue teams, such as firefighters or civil protection [46]. In the long term, the implementation of a support system is sought, consisting of a set of robots equipped with specialized sensors, such as infrared cameras, heat sensors, chemical sensors, remote control, among others, which would participate in the rescue tasks and maintain the security and integrity of the personnel as well as the already evident applications in the military sector in extremely dangerous tasks such as dealing with explosives and inspection minefields among many others [47]. In this article the design of the physical structure of the robot supported by a solid study of its possible locomotion and the possible means in which it will unfold, without forgetting the respective control stage to guarantee the delivery of an off-road device is presented.

\section{ll. Electronic Vision}

In the magazine of the Technological Faculty of Francisco José de Caldas University, some articles were found highlighting the study of CR for the rescue of victims.

In [48], a work is described based on the investigation of the applications of bioinspired and intelligent algorithms in the area of engineering in production at Francisco José de Caldas University. Hive artificial intelligence is applied as a metaheuristic tool for planning and optimizing the distribution problem in plant, aiming at finding the best spatial assignment for stations or work cells.

On the other hand, [49] describes, on the whole, the important aspects of parallel robots in order to have their applications known in different fields such as industry, architecture, mathematics that is required to analyze their mobility, kinematics, and dynamics. The investigations and future developments that can be carried out in the area of robotics are described, from a wide literature review.

Regarding the previous aspect, [50] presents an investigation about cooperative robotics through bioinspiration, that is, an algorithm is developed that seeks to imitate the emerging behaviors that occur in nature when the members of a hive interact locally, 
generating an intelligence to solve a problem in a selforganized way. That is why this article seeks to give a reference framework in the automation of picking warehouses.

In [51], a proposal for an algorithm for trajectory planning using a model of Brownian active particles $^{24}$ is presented. The artificial potential fields method possesses more popularity among the best known, but has a great disadvantage of presenting local minimums. The objective is to utilize a compact model that allows trajectory planning by evading local minimums.

[52] shows, a document that presents the stages in the development of a positioning and detection system implemented in a teleoperated pilot for a boat, in particular the design of a software developed in eMbedded Visual Basic $3 \AA$, for the location, on a digital map, the initial position of the boat and its navigation route, activation of the positioning system, programming and execution of the navigation algorithm in regard to two known points, and the detection of obstacles.

Within [53], a 2D localization technique for mobile robots is proposed. This mechanism is based on the use of multiple transmitters and at least one receiver located in the robot. The scope of the application is established in the need for a low cost in "disposable" robots for applications related to the detection of antipersonnel mines.

For [54], a review of commonly used techniques for the development and optimization of the planning of offline trajectories in serial robots is carried out. The information of the bioinspired algorithms is extracted thanks to its use as a search and optimization tool in problems of different areas of knowledge and the main applications in planning of off-line trajectories in which bioinspired algorithms have contributed as an alternative for the search and optimization of solutions in trajectories of serial robots is exposed.

\section{lll. Possible communications to be used}

According to the information gathered within this document, it is found that an emphasis has not been made yet regarding the part of the communications to be used within the $\mathrm{CR}$ projects, for this reason a comparative table is presented through which a development within the telecommunications part to be used within existing projects and make some kind of improvement or new project can be performed.

\begin{tabular}{|c|c|c|c|c|c|}
\hline \multicolumn{6}{|c|}{ TYPES OF COMMUNICATION } \\
\hline Technology & Definition & Required elements & Features & Functioning & Risks \\
\hline GPS & $\begin{array}{l}\text { Determines } \\
\text { the position } \\
\text { of an object } \\
\text { accurately. }\end{array}$ & $\begin{array}{l}\text { - Satellite } \\
\text {-Trilateration }\end{array}$ & $\begin{array}{l}\text {-24 satellites covering } \\
\text { the surface of Earth } \\
\text {-To position uses } \\
\text { minimum } 3 \text { satellites } \\
\text {-Height } 20200 \mathrm{~km} \\
\text {-Period: } 11 \text { h } 58 \mathrm{~min} \\
\text {-sSant: } 55 \text { grades (On } \\
\text { land Ecuador). } \\
\text {-Estimated useful life: } \\
7,5 \text { years } \\
\text {-Hour: } 1 \text { ns } \\
\text {-User capacity: } \\
\text { Unlimited } \\
\text {-Coordinate system }\end{array}$ & 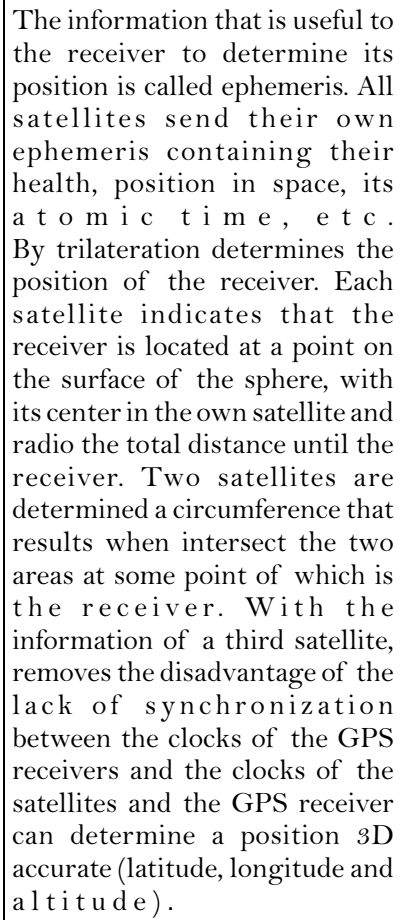 & $\begin{array}{l}\text {-Signal delay in } \\
\text { the ionosphere } \\
\text { and troposphere. } \\
\text {-Multipathing } \\
\text { signal, produced } \\
\text { by the rebound } \\
\text { of the signal in } \\
\text { nearby buildings } \\
\text { and mountains. } \\
\text {-Orbital errors, } \\
\text { where data from } \\
\text { the satellite orbit } \\
\text { is not completely } \\
\text { a c c u r a t e } \\
\text { - N u m b e r of } \\
\text { satellites visible. } \\
\text {-Geometry of } \\
\text { th e v i s i b l e } \\
\text { s a t e l l i t e s. } \\
\text {-Local errors in } \\
\text { the GPS clock. }\end{array}$ \\
\hline
\end{tabular}

${ }^{24}$ Random movement that is observed in the particles that are in a fluid medium (liquid or gas), as a result of collisions with the molecules of said fluid 


\begin{tabular}{|c|c|c|c|c|c|}
\hline \multicolumn{6}{|c|}{ TYPES OF COMMUNICATION } \\
\hline Technology & Definition & Required elements & Features & Functioning & Risks \\
\hline GPRS & $\begin{array}{c}\text { Service } \\
\text { oriented to } \\
\text { radio links } \\
\text { that gives } \\
\text { better } \\
\text { performanc } \\
\text { e to the } \\
\text { switching } \\
\text { of packages } \\
\text { in these } \\
\text { radio links. }\end{array}$ & $\begin{array}{l}\text { - Tw o-node G P R } \\
\text { support: The switching } \\
\text { node (SGSN) and the } \\
\text { gateway (GGSN) are } \\
\text { c o m p le m e n t a r y } \\
\text { functions. SGSN is } \\
\text { responsible for the } \\
\text { m a n a g m e n t o f } \\
\text { mobility and the } \\
\text { maintenance of the } \\
\text { logical link between } \\
\text { the phone and the } \\
\text { n e t w o } \mathrm{k} \text {. G G S N } \\
\text { provides access to IP- } \\
\text { based data networks. } \\
\text {-PCU (Packet Unit } \\
\text { Control) is responsible } \\
\text { for managing packet } \\
\text { c o m m u i c t i o n. } \\
\text {-The GPRS backbone } \\
\text { or IP-based backbone. }\end{array}$ & $\begin{array}{c}\text { - Transfer rate up to } 144 \\
\text { Kbps. } \\
\text { - Permanent connection. } \\
\text { Connection-setting time } \\
\text { lower than the second. } \\
\text { - Point-to-point service } \\
\text { (PTP): This is the ability to } \\
\text { connect in client-server mode } \\
\text { to a computer on an IP } \\
\text { network. } \\
\text { - Point service to multipoint } \\
\text { (PTMP): is the ability to send } \\
\text { packets to a group of } \\
\text { recipients (multicast). } \\
\text { - Short Message Service } \\
\text { (SMS). } \\
\text { - Payment by amount of } \\
\text { information transmitted, not }\end{array}$ & $\begin{array}{c} \\
\text { GTP: GPRS Tunneling } \\
\text { Protocol } \\
\text { SNDCP: Subnetwork } \\
\text { Dependent Convergence } \\
\text { AIR INTERFACE } \\
\text { DATA LINK LAYER } \\
\text { PHYSICAL LAYER } \\
\text { INTERFAZ BSS-SGSN } \\
\text { GMM/SM: GPRS } \\
\text { MOBILITY } \\
\text { MANAGEMENT/SESSION } \\
\text { MANAGEMENT } \\
\text {. }\end{array}$ & 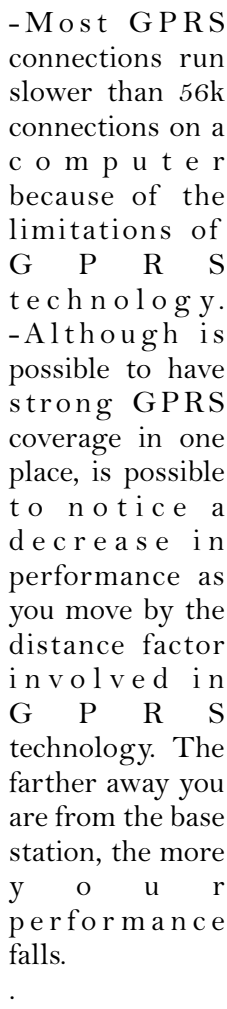 \\
\hline $\begin{array}{l}\text { SONAR/ } \\
\text { SODAR }\end{array}$ & $\begin{array}{c}\text { Sonar can be } \\
\text { used as a } \\
\text { means of } \\
\text { acoustic } \\
\text { localization, } \\
\text { operating in } \\
\text { a similar way } \\
\text { to the radar, } \\
\text { with the } \\
\text { difference } \\
\text { that instead } \\
\text { of emitting } \\
\text { electromagn } \\
\text { etic waves, it } \\
\text { uses sound } \\
\text { impulses. } \\
\text { The audible } \\
\text { signal can be } \\
\text { generated by } \\
\text { piezoelectrici } \\
\text { ty or by } \\
\text { magnetostric } \\
\text { tion }\end{array}$ & $\begin{array}{l}\text { Acoustic Base. } \\
\text { (Transductor) } \\
\text {-Selection and } \\
\text { switching. } \\
\text {-Transmitter. } \\
\text {-Receiver. } \\
\text {-Reading and } \\
\text { processing of the } \\
\text { received signal. }\end{array}$ & 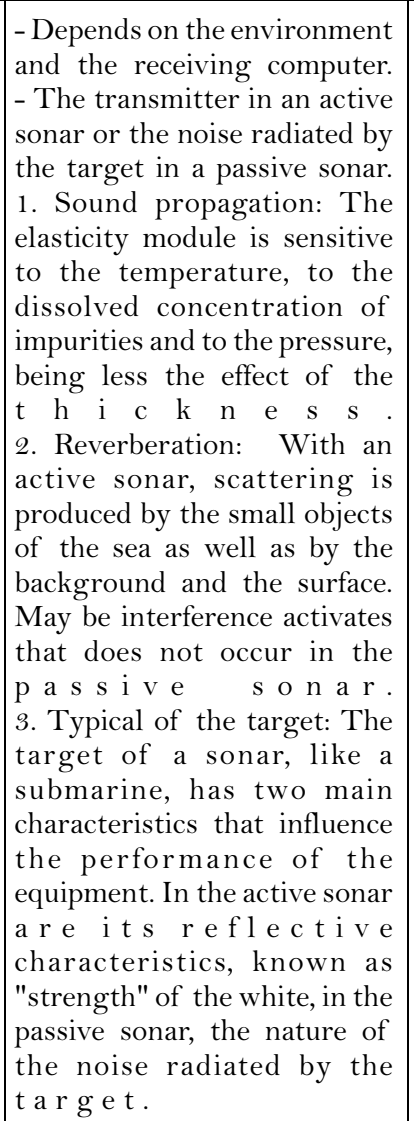 & 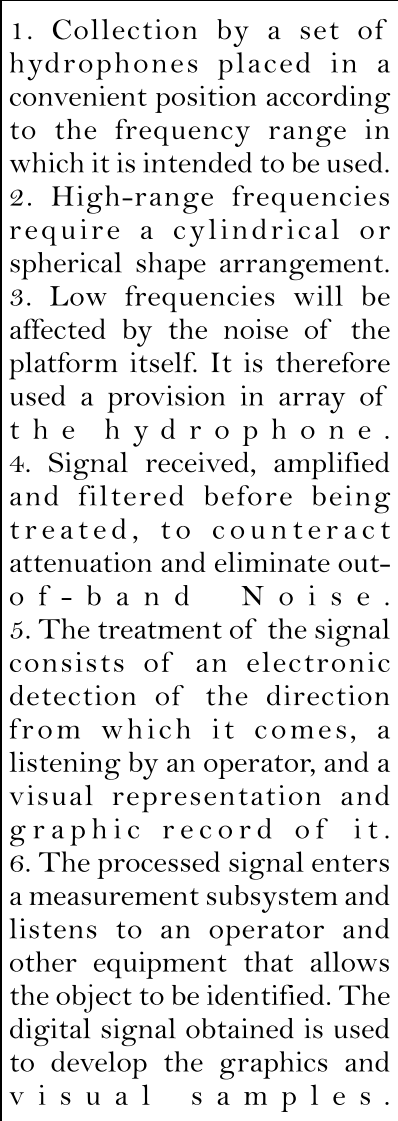 & $\begin{array}{c}\text { High-powered } \\
\text { sonar emitters } \\
\text { can affect marine } \\
\text { fauna, but you } \\
\text { don't know } \\
\text { exactly how. } \\
\text { Some marine } \\
\text { animals such as } \\
\text { whales and } \\
\text { dolphins use } \\
\text { sonar-like } \\
\text { ecolocation } \\
\text { systems that are } \\
\text { active to detect } \\
\text { predators and } \\
\text { prey. It is feared } \\
\text { that the sonar } \\
\text { emitters may } \\
\text { confuse these } \\
\text { animals. }\end{array}$ \\
\hline
\end{tabular}

Table 1. Types of communication. Source: own.

\footnotetext{
${ }^{24}$ Random movement that is observed in the particles that are in a fluid medium (liquid or gas), as a result of collisions with the molecules of said fluid Visión Electrónica: Algo mas que un estado sólido ISSN 1909-9746 E-ISSN 22484728 Volume 1 number 2- Special edition July-December 2018
} 


\section{Conclusions}

In Latin America, research in Cooperative Robotics CR is recent, since it can be seen that in the period investigated within the last decade is where more documentation is found. In Colombia, most of the projects developed are at the educational level; but it can also be included that all the developments and studies carried out can be implemented towards the rescue of victims using cooperative robotics.

In the selected sectoral pattern, it is found that the largest number of references cited by other articles is in the education sector that is equivalent to $30 \%$ in research with 4 , in design with 3 and in development with 5 . The successive sector that most references were consulted is in industry that counts for $25 \%$ containing control architecture 4 documents, in decentralized control 3 and in centralized control 3. In third place there is Rescue of victims which is $22.5 \%$ with 2 written articles on locomotion and 7 published in the magazine Visión Electrónica. In fourth place it comes Security with $20 \%$ where there are 4 articles in location and 5 in detection. And coming to fifth place health with 1 article which corresponds to $2.5 \%$ of the total of documents searched.

According to the above, a basis for research and future developments that are desired to be performed within the educational, social or business environment is left for granted.It is expected that with the comparative table presented, studies and implementations can be made in order to help with the improvement in the communications within $\mathrm{CR}$ as well as in the rescue of victims. Since this approach was developed simultaneously with the investigation of the CR in recent years in Latin America.

\section{References}

[1] T. Fukuda, S. Nakagawa, M. Buss and Y. Kawauchi, "Structure decision method for self organizing robots based on cell structuresCEBOT”, Proceedings, 1989 International Conference on Robotics and Automation, 1989. https://doi.org/10.1109/ROBOT.1989.10006 $\underline{6}$.

[2] P. Caloud, W. Choi, J. Latombe, C. Le Pape and M. Yim, "Indoor automation with many mobile robots", IEEE International Workshop on Intelligent Robots and Systems, Towards a New Frontier of Applications, 1990. https://doi.org/10.1109/IROS.1990.262370.
F. R. Noreils, "Toward a Robot Architecture Integrating Cooperation between Mobile Robots: Application to Indoor Environment", The international journal of robotics research, vol. 12, n o. 1, 1993 , p p . $79-98$. https://doi.org/10.1177/0278364993012001 o6.

[4] C. Kube, H. Zhang and X. Wang, "Controlling Collective Task with ALN", Proceedings of 1993 IEEE/RSJ International Conference on Intelligent Robots and Systems (IROS '93), $\begin{array}{llll}1 & 9 & 9 & 3\end{array}$ https://doi.org/10.1109/IROS.1993.583112.

[5] J. Meyer, H. Roitblat and S. Wilson, "From animals to animats 2 ”, Cambridge: Mass.: MIT Press; 1993.

[6] R. Barman, S. Kingdon, A. K. Mackworth, D. K. Pai, M. K. Sahota, H. Wilkinson and Y. Zhang, "Dynamite: A Testbed for Multiple Mobile Robots 1", 1993. [Online]. Available at: https://www.semanticscholar.org/paper/Dyn amite-\%3A-A-Testbed-for-Multiple-Mobile$\underline{\mathrm{R}} \mathrm{o}$ b o t $\mathrm{s}-1$ - B a r m a n Kingdon/ac6b2b062b864083b593e547ef50b9 73e91630bf? navId=extracted.

[7] L. Panait and S. Luke, "Cooperative MultiAgent Learning: The State of the Art", Autonomous Agents and Multi-Agent Systems, vol. 11, no. 3, 2005, p p. $387-434$. https://doi.org/10.1007/s 10458-005-2631-2.

[8] L. Parker, "An Experiment in Mobile Robotic Cooperation", Proceedings of the ASCE Specialty Conference on Robotics for Challenging Environments, 1993, pp. 131-139.

[9] B. Donald, J. Jennings and D. Rus, "Towards a Theory of Information Invariants for Cooperating Autonomous Mobile Robots", Cornell University Ithaca, NY, USA, 1993.

[10] R. Beckers, O. E. Holland and J. L. Deneubourg, "From Local Actions to Global Tasks: Stigmergy and Collective Robotics”, CP 231, B-1050 Brussels, 1994, pp. 181-189.

[11] RoboCup Federation official website, "A Brief History of RoboCup", 2016. [Online]. 
- Available at:

https://www.robocup.org/a_brief_history_o.. frobocup.

[12] R. Hernández Sampieri, C. Fernandez Collado and P. Baptista Lucio, "Metodología de la investigación”, México: Mc Graw Hill, 2010.

[13] G. D. Tejera López, "Contribución al diseño de sistemas multi robots utilizando ALLIANCE”, thesis Msc., Universidad de la República, Uruguay, 2004.

[14] G. P. Cano-Usiña and D. J. Palaquibay-Inga, "Control cooperativo de robots utilizando FPGA's", thesis, Escuela Politécnica Nacional, Ecuador, 2014.

[15] E. A. Beltrán-González, “Transporte cooperativo de objetos con una plataforma móvil en un entorno estructurado", Redes de Ingeniería, vol. 3, no. 1, 2012. https://doi.org/10.14483/2248762X.6404.

[16] R. Mosquera, "Diseño de un algoritmo de enjambre para el trabajo colaborativo de mini robots para recoger y clasificar piezas de diferentes formas y colores. Propuesta de semillero de investigación SYNAP”, 4to Congreso Internacional AmITIC 2017, Aplicando nuevas tecnologías, 2017, pp. 218-223.

[17] P. Baena, A. Escamilla and J. Obando, "Diseño e implementación de un equipo de robots autónomos cooperativos", thesis, Universidad Pontificia Bolivariana, Medellín, 2014.

[18] M. A. Molina-Villa and E. L. RodríguezVásquez, "Flotilla de robots para trabajos en robótica cooperativa", thesis, Universidad Militar Nueva Granada, Colombia, 2014.

[19] J. R. Camargo-López, N. J. Hernández-Suárez and A. Rodríguez-Tibaduiza, "Sistema de transporte y embalaje utilizando robótica cooperativa basada en teoría de colonias de hormigas mediante plataforma MINDSTORM DE LEGO®”, Redes de ingeniería, vol. 6, no. 1, $\begin{array}{lllll}2 & 0 & 1 & 5\end{array}$.

https://doi.org/10.14483/udistrital.jour.rede s.2015.1.a04.

[20] G. Vargas-Torres, "Sistema para manipulación y transporte de canaletas usando robótica cooperativa", thesis, Universidad Militar Nueva Granada, Colombia, 2012.

[21] G. A. Sanmiguel "Diseño e implementación de un sistema multi-agente robótico móvil para tareas cooperativas", Bogotá, 2016. [Online]. A v a i l a b l e a t : https://core.ac.uk/display/147664251.

[22] L. E. Solaque-Guzmán, D. R. Avendaño-Florez, M. A. Molina-Villa and C. A. Pulido-Rojas, "Sistema de transporte cooperativo desarrollado para un grupo de robots móviles no-holonómicos usando el método líder virtual", IV Congreso internacional de ingeniería, mecatrónica y automatizaciónCIIMA, 2015, pp. 264-272.

[23] V. Da Camara and M. F. Campos, "Localização e mapeamento simultâneos em robótica cooperativa com planejamento: Uma revisão", Brasil, 2009. [Online]. Available at: https://fei.edu.br/sbai/SBAI2009/artigos/SI \begin{tabular}{llllllllllllll}
$\mathrm{S}$ & $\mathrm{T}$ & $\mathrm{E}$ & $\mathrm{M}$ & $\mathrm{A}$ & $\mathrm{S}$ & $\%$ & 2 & 0 & $\mathrm{M}$ & $\mathrm{U}$ & $\mathrm{L}$ & $\mathrm{T}$ & $\mathrm{I}$ \\
\hline
\end{tabular} $\underline{\mathrm{ROB} \% \mathrm{C} 3 \% 94 \mathrm{~S} / 55795 . \mathrm{pdf}}$.

[24] G. Bermúdez, K. Novoa and W. Infante, "La robótica en actividades de búsqueda y rescate urbano. Origen, actualidad y perspectivas", Tecnura, vol. 8, no. 15, 2004, pp. 97-108. https://doi.org/10.14483/22487638.6165.

[25] J. S. Figueredo and A. F. Caicedo, "MRCC Robótica Cooperativa: Una Perspectiva Práctica de Cooperación Entre Robots", thesis, Pontificia Universidad Javeriana, Colombia, 2009.

[26] L. C. Romero-Lancheros, "Propuesta didáctica para estimular la creatividad haciendo uso de robots cooperativos", thesis, Universidad Distrital Francisco José de Caldas, Colombia, 2012.

[27] Y. Cuenca, "Robótica Colectiva: Tendencia en el Enfoque de diseño", Revistas bolivianas, 2012, 
pp. 133-140. [Online]. Available at: http://www.revistasbolivianas.org.bo/pdf/rit /n1/n1_a15.pdf.

[28] F. Roberti, J. Toibeiro, R. Frizera and R. Vassallo, "Control Estable de Formación Basado en Visión Omnidireccional para Robots Móviles No Holonómicos”, Revista Iberoamericana de Automática e Informática Industrial RIAI, vol. 8, no. 1, 2011, pp. 29-37. https://doi.org/10.1016/S16977912(11)70005-X.

[29] C. F. González-Torres, "Plataforma para robótica cooperativa soportada por teléfonos inteligentes Android”, thesis Msc., Pontificia Universidad Javeriana, Colombia, 2015.

[30] L. Payá, O. Reinoso, A. Gil and L. Jiménez, "Plataforma Distribuida para la Realización de Prácticas de Robótica Móvil a través de Internet”, Información Tecnológica, vol. 18 no. 6, $2007, \quad \mathrm{p} \mathrm{p} . \quad 27-38$. http://dx.doi.org/10.4067/So $718-$ 07642007000600005.

[31] L. Di Matteo, A. Mangone and M. Muzzio, "Equipo de Fútbol de Robots UTNfrba”, Buenos Aires, Argentina, 2009. [Online]. A v a i l a b l e a t : https://studylib.es/doc/609229/equipode-f\%C3\%BAtbol-de-robots-utnfrba. A v a i l a b l e a t : https://studylib.es/doc/609229/equipode-f\%C3\%BAtbol-de-robots-utnfrba.

[32] R. Muñoz-González, "ProPAC - Protocolo de pruebas de acciones cooperativas para robots futbolistas", thesis, Pontificia Universidad Javeriana, Colombia, 2011.

[33] E. González-Guerrero, J. Páez-Rodríguez and F. Roldán, "Uso de robots cooperativos para el desarrollo de habilidades de trabajo cooperativo en niños”, Revista de Investigaciones $U N A D$, vol. 12, no. 2, 2013. https://doi.org/10.22490/25391887.1175.

[34] R. S. Daza-Leiva, "Desarrollo de una interfaz ethernet enfocada al laboratorio remoto para aplicación de robótica cooperativa”, thesis,
Universidad Militar Nueva Granada, Colombia, 2014.

[35] B. Caizaluisa-Guerra and M. A. Morocho-Oña, "Diseño e implementación de un sistema robótico móvil cooperativo para detección y análisis de incendios en ambientes controlados", thesis, Universidad de las Fuerzas Armadas, Ecuador, 2016.

[36] F. Castañón-Decena, C. Cosme-Bustamante and C. Martínez-Tovar, "Robot Móvil para reconocimiento de terrenos”, thesis, Instituto Politécnico Nacional, México, 2011.

[37] A. Rojas-Pacheco and J. Medel-Juárez, "Control Cooperativo Aplicado a la Formación de Robots Autónomos Múltiples”, 2do. Simposio de Tecnología Avanzada CICATA-IPN, México D. F., 2008.

[38] G. R. Bermúdez-Bohórquez, C. A. MancipeBernal and J. E. Ortiz-Velásquez, "Control de un convoy robótico mediante planificación de rutas y estrategias de orientación”, Revista Cientifica, vol. 3, no. 30, 2017. https://doi.org/10.14483/23448350.12305.

[39] B. O. Caizaluisa-Guerra and M. A. MorochoOña, "Diseño e implementación de un sistema robótico móvil cooperativo para detección y análisis de incendios en ambientes controlados", thesis, Universidad de las Fuerzas Armadas, Ecuador, 2016.

[40] J. P. López-Goyes and P. J. Sandoval-Vizuete, "Implementación y optimización de algoritmos de búsqueda de fuentes de olor basados en robótica cooperativa”, thesis, Universidad de las Fuerzas Armadas, Ecuador, 2017.

[41] P. A. Romero-Macas, "Análisis de la posición y tiempo de detección para dispositivos móviles en un sistema de posicionamiento local en espacios interiores basado en el estándar IEEE 802.11 mediante la técnica Fingerprints y el filtro de Kalman, para aplicaciones de robótica cooperativa”, thesis, Universidad de las Fuerzas Armadas, Ecuador, 2017.

[42] F. A. Bertel and M. Gamarra, "Navegación Robótica Multiagente Orientado a Estrategias 
de Vigilancia Cooperativa Implementando Algoritmos Inteligentes en un Entorno de Simulación", Twelfth LACCEI Latin American and Caribbean Conference for Engineering and Technology, Guayaquil, Ecuador, 2014.

[43] D. Vélez-Díaz and S. S. Moreno-Gutiérrez, "Sistemas inteligentes en exoesqueletos de rehabilitación”, 2013. [Online]. Available at: https://www.uaeh.edu.mx/scige/boletin/tlah uelilpan/n1/es.html.

[44] R. A. García-García and M. Arias-Montiel, "Prototipo virtual de un robot móvil multiterreno para aplicaciones de búsqueda y rescate", Ingeniería Mecatrónica en México 2016.

[45] W. Ayala-Peñaranda and J. D. Rojas-Ortega, "Prototipo robótico auxiliar para labores de búsqueda y rescate", Revista de tecnología, vol. 9, no. $1,2010$.

[46] N. Rátiva, "Firebot: Un bombero electrónico para Colombia", 2007. [Online]. Available at: http://noticias.universia.net.co/vidauniversitaria/noticia/2007/08/13/249561/fir ebot-bombero-electronico-colombia.html.

[47] A. Díaz, "Robot contra minas antipersona", 2006. [Online]. Available at: http://noticias.universia.net.co/vidauniversitaria/noticia/2006/05/18/25728 7/robot-contra-minas-antipersona.html.

[50] C. L. González-Pinzón, H. E. Espitia-Cuchango and G. Avendaño-Prieto, "Marco de desarrollo algorítmico de inteligencia de enjambres aplicada en almacenes", Visión Electrónica, vol. 9, n o. 2, 2015, p p. $194-205$. https://doi.org/10.14483/22484728.11028.

[51] H. E. Espitia-Cuchango and J. SofronyEsmeral, "Algoritmo para la planeación de trayectorias de robots móviles empleando enjambres de partículas brownianas", Visión Electrónica, vol. 5, no. 1, 2011, pp. 4-14. https://doi.org/10.14483/22484728.3516.

[52] A. Escobar-Díaz, J. Calderón-Acero and I. Parra-Garzón, "Prototipo Teleoperado: Una alternativa en sistemas de búsqueda de personas", Visión Electrónica, vol. 2, no. 2, 2008, p p . $78-85$. https://doi.org/10.14483/22484728.798.

[53] E. J. Saavedra-Mercado, "Sistema de localización acústico para robots móviles basado en múltiples transmisores y un receptor", Visión Electrónica, vol. 1, no. 1, 2008, p p . $32-40$. https://doi.org/10.14483/22484728.248.

[54] M. A. Guzmán and C. Peña, "Algoritmos bioinspirados en la planeación off-line de trayectorias de robots seriales, Visión Electrónica, vol. 7, no. 1, 2013, pp. 27-39. https://doi.org/10.14483/22484728.4390. 